\title{
Periurethral abscess complicating gonococcal urethritis: case report and literature review
}

\author{
A. Kenfak-Foguena $\cdot$ Y. Zarkik $\cdot$ M. Wisard • \\ V. Praz $\cdot$ K. E. A. Darling $\cdot$ K. Jaton-Ogay • \\ P. Jichlinski $\cdot$ M. Cavassini
}

Received: 17 May 2010/Accepted: 3 August 2010/Published online: 3 September 2010

(C) Urban \& Vogel 2010

Periurethral abscess formation secondary to urethritis has become an atypical and rare urological complication. We report here a case of penile gonococcal periurethral abscess and review the literature. Chart review and writing of the manuscript have been approved by the Ethical Committee of the Faculty of Biology and Medicine of Lausanne University, Switzerland.

In February 2007, a 46-year-old HIV-positive homosexual man was admitted to the Urology Clinic of the University Hospital of Lausanne for a painful cherry-sized

P. Jichlinski and M. Cavassini contributed equally to this work.

A. Kenfak-Foguena - K. E. A. Darling · M. Cavassini $(\bowtie)$ Infectious Diseases Service, Centre Hospitalier Universitaire Vaudois and Lausanne University, 1011 Lausanne, Switzerland e-mail: matthias.cavassini@chuv.ch

\author{
A. Kenfak-Foguena \\ e-mail: alain.kenfak-foguena@chuv.ch \\ K. E. A. Darling \\ e-mail: katharine.darling@chuv.ch
}

Y. Zarkik · M. Wisard · V. Praz · P. Jichlinski

Department of Urology, Centre Hospitalier Universitaire

Vaudois and Lausanne University, Lausanne, Switzerland

e-mail: yassine.zarkik@chuv.ch

M. Wisard

e-mail: marc.wisard@chuv.ch

V. Praz

e-mail: valentin.praz@chuv.ch

P. Jichlinski

e-mail: patrice.jichlinski@chuv.ch

\section{K. Jaton-Ogay}

Institute of Microbiology, Centre Hospitalier Universitaire Vaudois and Lausanne University, Lausanne, Switzerland e-mail: katia.jaton-ogay@chuv.ch mass of the distal penis. One week before the admission, he had consulted the outpatient emergency unit with a history of urethral discharge which was diagnosed clinically as gonococcal urethritis and treated with $400 \mathrm{mg}$ of ofloxacin, single dose.

On physical examination, the patient presented a good general status and was afebrile. Examination of the external genitalia revealed a tender mass $2 \mathrm{~cm}$ in diameter affecting the ventral aspect of the penis, close to the balano-preputial separation (Fig. 1a). The overlying skin was intact. There was no discharge, no ulceration, and no palpable lymphadenopathy. The C-reactive protein value and blood leucocytes count were within normal limits. Syphilis serology was positive with a VDRL titer of 2 and a TPHA titer of 1,280. Blood and urine cultures were negative. Penile ultrasound scan showed a hypo-echogenic collection adjacent to the distal penile urethra and spongy urethra measuring $20 \times 15 \times 10 \mathrm{~mm}$ (Fig. 1b). Retrograde urography and urethroscopy demonstrated normal urethral mucosa. The urethral lumen was narrowed by a bulging mass originating from outside the urinary tract. There was no communication between the mass and the urinary tract. Regarding the HIV infection, the CD4 lymphocyte count was 91 cells $/ \mathrm{mm}^{3}(18 \%)$ and the HIV viral load was $2,300 \mathrm{copies} / \mathrm{ml}$. (The patient had recently stopped his antiretroviral treatment.)

A combined medical and surgical approach was required. Following a 5 -day course of ceftriaxone $2 \mathrm{~g}$ once daily intravenously, the abscess did not decrease in size. The abscess was, thus, incised and drained completely by performing a transurethral endoscopic incision of the abscess using the Collins loop of a 24 French resectoscope. A urethral Foley catheter was then inserted and kept in place for 3 days. Gram stain and culture of the pus failed to identify any germ. A real-time in-house polymerase chain 

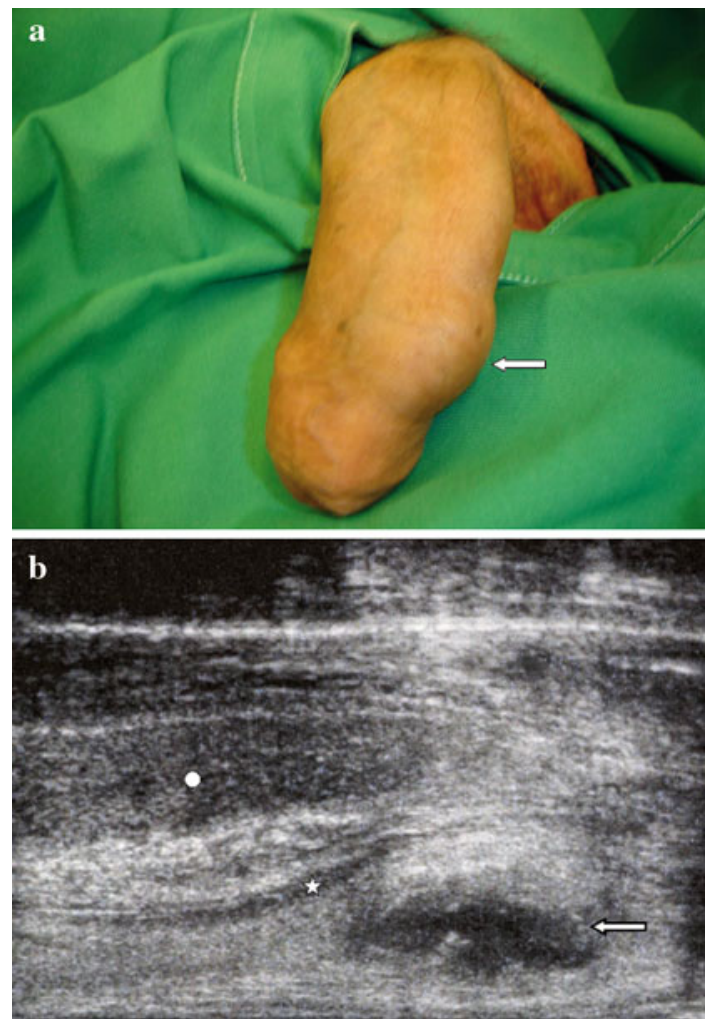

Fig. 1 Penile abscess: a physical examination, b ultrasonography; circle corpus cavernosum, star urethra, arrows periurethral abscess

reaction (PCR) assay specific for Neisseria gonorrhoeae, targeting the porA gene (with sensitivity and specificity comparable to Amplicor), was performed on the pus and gave a positive result $\left(342\right.$ copies $\left./ \mathrm{mm}^{3}\right)$. PCR analysis specific for Chlamydia trachomatis was negative.

The patient developed a generalized erythrodermia with palpebral and facial edema on ceftriaxone and this treatment was changed to imipenem to complete a 10-day antibiotic course. His HIV antiretroviral therapy was resumed during hospitalization.

During a 2-year followup period post-treatment, the patient has remained well, with no abscess recurrence and no symptoms of urethral obstruction or stricture.

Gonococcal infection remains the second most common sexually transmitted infection (STI) worldwide after chlamydia [1]. Major risk groups are young people, females, men who have sex with men (MSM), and low socioeconomic populations [2]. Our patient's risk behavior for acquiring another STI was unprotected oral sex with other men. Gonococcal infection is more frequent in the HIVpositive population, but it is not clear whether HIV per se increases the risk of infection or if other factors such as high risk behavior act as confounders [2, 3].

The clinical presentation of gonorrhoea depends on the involved mucosa. Some patients may not develop symptoms, while others will present with complications, according to the degree of virulence of the infecting strains [4] and the involved mucosa (rectum and pharynx are less symptomatic than urogenital mucosa) [5]. Recurrent infections also increase the risk of complications such as pelvic inflammatory diseases (PID), tubal scarring, or periurethral abscesses.

Before the use of adequate antibiotic treatment, the formation of periurethral abscesses was a typical ascending complication of gonococcal urethritis in men. It has become rare in the past three decades [6] and, nowadays, is usually described in case reports or small series (Table 1) [7-14]. In the study conducted by Sanders and Mulder [14], $N$. gonorrhoeae accounted for 3/20 culture-confirmed periurethral abscesses. Abscess formation is usually associated with a delay in the diagnosis of gonococcal urethritis or the presence of a urethral stricture. Periurethral abscess usually develops when a Littré gland (and rarely a Tyson gland) becomes obstructed by thickened pus or by fibrosis. However, it may also occur through urethral crypts or through the balano-preputial separation. Another risk factor for gonococcal abscess may be a cutaneous trauma allowing direct inoculation of the bacteria [7].

Gonococcus can be detected in biological samples by several methods. The Gram stain is a sensitive and specific test for diagnosing symptomatic male urethral gonorrhea. However, the gold standard for the diagnosis is growth of the organism on chocolate agar or on Thayer-Martin agar and confirmatory tests include carbohydrate acidification tests, chromogenic enzyme substrate tests, and immunologic tests [15]. Nucleic acid amplification tests (NAATs) are more sensitive and faster than culture, and are, nowadays, commonly used [16], but they do not provide information on bacterial susceptibility to antibiotics. When available, the NAATs have largely replaced culture. Other methods of diagnosis are point-of-care testing (POC), such as immuno-chromatographic strip tests or optical immunoassays performed on urine, endocervical, and vaginal swabs, which allow diagnosis and treatment in a single visit. These tests have a high specificity but lower sensitivity compared to NAATs [17]. Medical imaging is useful to delineate and confirm the diagnosis of periurethral abscesses. Penile ultrasonography is usually sufficient; computed tomography (CT) and magnetic resonance imaging (MRI) add no significant information and are, therefore, of little use.

There are no randomized trials evaluating the management of periurethral abscesses. Treatment approaches tend to be based on surgeons' experience and abscess location. Recommended management include antibiotic therapy and drainage, the latter being performed by needle aspiration, open surgery, or endoscopic transurethral incision. In our patient, the location of the abscess in the periurethral distal 
Table 1 Periurethral gonococcal abscess in the literature (1980-2009)

\begin{tabular}{|c|c|c|c|c|}
\hline Reference & $\begin{array}{l}\text { Number } \\
\text { of cases }\end{array}$ & Clinical presentation & Diagnostic procedure & Treatment \\
\hline Kraus et al. [7] & 1 & $\begin{array}{l}\text { Bagatelle penile trauma } \\
\text { No voiding dysfunction, no hematuria, no } \\
\text { urethral discharge }\end{array}$ & $\begin{array}{l}\text { Pus analysis: Gram stain and ELISA } \\
\text { Penile ultrasonography } \\
\text { Sono-urethrography with retrograde } \\
\text { saline infusion to the distal urethra }\end{array}$ & $\begin{array}{l}\text { Surgical incision using a } \\
\text { Turner-Warwick } \\
\text { Cephalosporin- } \\
\text { aminoglycoside bolus, } \\
\text { then cefuroxim for } 7 \text { days }\end{array}$ \\
\hline $\begin{array}{l}\text { Komolafe et al. } \\
\text { [8] }\end{array}$ & 1 & $\begin{array}{l}\text { Urethral discharge } \\
\text { Painful lump in the penis with a striking } \\
\text { erythema of the penile shaft }\end{array}$ & Urethral smear and culture & $\begin{array}{l}\text { Surgical drainage of pus } \\
\text { Ciprofloxacin and } \\
\text { amoxicillin-clavulanic } \\
\text { acid (+metronidazole) }\end{array}$ \\
\hline $\begin{array}{l}\text { Yamada and Ito } \\
\text { [9] }\end{array}$ & 1 & $\begin{array}{l}\text { Mass of the prepuce not accompanied } \\
\text { with urethritis }\end{array}$ & $\begin{array}{l}\text { Not available in the abstract (article in } \\
\text { Japanese) }\end{array}$ & Cefodizime IV \\
\hline \multirow[t]{3}{*}{$\begin{array}{l}\text { Neubert et al. } \\
\text { [10] }\end{array}$} & 3 & $\begin{array}{l}\text { Pus-filled nodule in the dorso-regional } \\
\text { region of the prepuce } \\
\text { No urethral discharge or burning }\end{array}$ & $\begin{array}{l}\text { Gram stain of a smear from the } \\
\text { abscess and urethra and culture on } \\
\text { modified Thayer-Martin agar }\end{array}$ & $\begin{array}{l}\text { Penicillin bolus and } \\
\text { probenecid per os } \\
\text { Surgical drainage of } \\
\text { abscess }\end{array}$ \\
\hline & & $\begin{array}{l}\text { Painful preputial nodule with ulceration } \\
\text { of the prepuce } \\
\text { No discharge, no pain }\end{array}$ & $\begin{array}{l}\text { Pus culture on modified Thayer- } \\
\text { Martin plate }\end{array}$ & $\begin{array}{l}\text { Spectinomycin } 2 \mathrm{~g} \text { single } \\
\text { dose }\end{array}$ \\
\hline & & $\begin{array}{l}\text { Preputial nodule without discharge or } \\
\text { burning }\end{array}$ & Examination of pus and urethra smear & Cefotiam $1 \mathrm{~g}$ single dose \\
\hline $\begin{array}{l}\text { Fiumara and } \\
\text { Eisen [11] }\end{array}$ & 1 & $\begin{array}{l}\text { 8-mm inflammatory mass of the prepuce. } \\
\text { No discharge, no dysuria }\end{array}$ & $\begin{array}{l}\text { Gram stain and culture on Thayer- } \\
\text { Martin agar }\end{array}$ & $\begin{array}{l}\text { Procaine penicillin } \mathrm{G} \text { single } \\
\text { dose IM }\end{array}$ \\
\hline $\begin{array}{l}\text { Clifford et al. } \\
\text { [12] }\end{array}$ & 1 & $\begin{array}{l}\text { Discharge from a mass of the median } \\
\text { raphe, associated to urethritis }\end{array}$ & Culture of the discharge & $\begin{array}{l}\text { Amoxicillin and probenecid } \\
\text { bolus then amoxicillin per } \\
\text { os }\end{array}$ \\
\hline $\begin{array}{l}\text { Subramanian } \\
\text { [13] }\end{array}$ & 1 & $\begin{array}{l}\text { Urethral discharge } \\
\text { Tender swelling of } 1 \mathrm{~cm} \text { on each side of } \\
\text { the frenum and another swelling at the } \\
\text { inferior aspect of the penis }\end{array}$ & $\begin{array}{l}\text { Microscopy of Gram-stained urethral } \\
\text { material }\end{array}$ & $\begin{array}{l}\text { Ampicillin and probenecid } \\
\text { for } 10 \text { days }\end{array}$ \\
\hline $\begin{array}{l}\text { Sanders and } \\
\text { Mulder [14] }\end{array}$ & $3 / 16$ & $\begin{array}{l}\text { Consecutive series of patients with a } \\
\text { clinical diagnosis of periurethral abscess }\end{array}$ & $\begin{array}{l}\text { Urethral and endo-urethral swabs } \\
\text { Pus culture }\end{array}$ & $\begin{array}{l}\text { Needle aspiration of pus } \\
\text { Kanamycin single dose and } \\
\text { doxycycline for } 1 \text { week }\end{array}$ \\
\hline
\end{tabular}

Articles retrieved from PubMed on 1st December 2009. Search words: periurethral abscess or urethritis and gonorrhoea

penis made it easily accessible to endoscopic transurethral incision. Antibiotic coverage is important to prevent septicemia [18]. Recommended antibiotics for the treatment of uncomplicated gonococcal urethritis are third-generation cephalosporins which can be given as a single dose (for example, ceftriaxone and cefixime) [19]. In the case of abscess formation, antibiotic treatment is generally continued for at least 7 days. With the increased prevalence of resistant strains, fluoroquinolones are no longer recommended as the first-line treatment [20]. In our patient, the progression of urethritis to an abscess may have been due either to delay prior to consultation or to ofloxacin resistance in the infecting strain. As the detection of gonococcus was performed by PCR following a 5-day course of ceftriaxone, we do not have the data regarding the strain's sensitivity.

After appropriate treatment, outcome is usually good. However, abscess recurrence can occur, as can other complications, such as urethral stricture, urethrocutaneous fistula, or urethral diverticulum [6, 14]. To date, our patient has not presented any sequelae following the treatment of his abscess.

Conflict of interest None declared.

\section{References}

1. Centers for Disease Control and Prevention (CDC). Sexually transmitted disease surveillance, 2006. Atlanta, GA: US Department of Health and Human Services, CDC 2007. Available online at: http://www.cdc.gov/std/stats06/toc2006.htm. Accessed 11 Jun 2009.

2. Delpech V, Martin IM, Hughes G, et al. Epidemiology and clinical presentation of gonorrhoea in England and Wales: findings from the Gonococcal Resistance to Antimicrobials 
Surveillance Programme 2001-2006. Sex Transm Infect. 2009;85(5):317-21.

3. Zetola NM, Bernstein KT, Wong E, et al. Exploring the relationship between sexually transmitted diseases and HIV acquisition by using different study designs. J Acquir Immune Defic Syndr. 2009;50(5):546-51.

4. Edwards JL, Apicella MA. The molecular mechanisms used by Neisseria gonorrhoeae to initiate infection differ between men and women. Clin Microbiol Rev. 2004;17(4):965-81.

5. Kent CK, Chaw JK, Wong W, et al. Prevalence of rectal, urethral, and pharyngeal chlamydia and gonorrhea detected in 2 clinical settings among men who have sex with men: San Francisco, California, 2003. Clin Infect Dis. 2005;41(1):67-74.

6. Walther MM, Mann BB, Finnerty DP. Periurethral abscess. J Urol. 1987;138(5):1167-70.

7. Kraus S, Luedecke G, Ludwig M, et al. Periurethral abscess formation due to Neisseria gonorrhoeae. Urol Int. 2004;73(4): 358-60.

8. Komolafe AJ, Cornford PA, Fordham MV, et al. Periurethral abscess complicating male gonococcal urethritis treated by surgical incision and drainage. Int J STD AIDS. 2002;13(12):857-8.

9. Yamada Y, Ito K. Gonococcal abscess in the prepuce: a case report. Kansenshogaku Zasshi. 2001;75(9):819-21.

10. Neubert U, Korting HC, Luderschmidt C, et al. Preputial abscesses caused by beta-lactamase-producing gonococci. Cutis. 1985;36(2):161-3.
11. Fiumara NJ, Eisen R. Cutaneous gonococcal abscess: a case report. Sex Transm Dis. 1984;11(1):34-5.

12. Clifford GR, Krieger JN, Rein MF. Gonococcal infection of the median penile raphe. J Urol. 1983;130(1):138-9.

13. Subramanian S. Gonococcal urethritis with bilateral tysonitis and periurethral abscess. Sex Transm Dis. 1981;8(2):77-8.

14. Sanders CJ, Mulder MM. Periurethral gland abscess: aetiology and treatment. Sex Transm Infect. 1998;74(4):276-8.

15. Workowski KA, Berman SM. Sexually transmitted diseases treatment guidelines, 2006. MMWR Recomm Rep. 2006;55(RR11):1-94

16. Cook RL, Hutchison SL, Ostergaard L, et al. Systematic review: noninvasive testing for Chlamydia trachomatis and Neisseria gonorrhoeae. Ann Intern Med. 2005;142(11):914-25.

17. Greer L, Wendel GD Jr. Rapid diagnostic methods in sexually transmitted infections. Infect Dis Clin North Am. 2008;22(4): 601-17.

18. Malatinsky E. Sepsis caused by periurethral abscess. Int Urol Nephrol. 1991;23(5):485-8.

19. Bignell C. 2009 European (IUSTI/WHO) guideline on the diagnosis and treatment of gonorrhoea in adults. Int J STD AIDS. 2009;20(7):453-7.

20. Centers for Disease Control and Prevention (CDC). Update to CDC's sexually transmitted diseases treatment guidelines, 2006: fluoroquinolones no longer recommended for treatment of gonococcal infections. MMWR Morb Mortal Wkly Rep. 2007;56:332-6. 